\title{
Occult Plummer Vinson syndrome in a patient with haemorrhoids
}

\author{
Robin George Manappallil', Shanija P' ${ }^{2}$, Ramesh Naga Supreeth ${ }^{3}$ \\ ${ }^{1}$ Consultant- Physician, ${ }^{3}$ Resident, Department of Internal Medicine, ${ }^{2}$ Consultant-Gastroenterologist, Department of \\ Gastroenterology, Baby Memorial Hospital, Calicut, Kerala, India
}

Plummer Vinson syndrome is a rare condition characterised by the triad of dysphagia, irondeficiency anaemia and upper oesophageal webs. This is a case of a middle aged lady who presented with fatigue and was diagnosed to have iron deficiency anaemia. She did not have any complaints of dysphagia. On endoscopic evaluation she was found to have post cricoid web and haemorrhoids. Since post cricoid webs can complicate to squamous cell carcinoma of gastrointestinal tract, this case highlights the importance of endoscopic evaluation of all patients presenting with severe iron deficiency anaemia even in the absence of dysphagia, to rule out occult Plummer Vinson syndrome.
Access this article online Website:

http://nepjol.info/index.php/AJMS DOI: 10.3126/ajms.v8i3.17005 E-ISSN: 2091-0576 P-ISSN: $2467-9100$

Key words: Plummer Vinson syndrome, Iron deficiency anaemia, Post cricoid webs

\section{INTRODUCTION}

The development of post cricoid web is a rare complication of iron deficiency anaemia (IDA). The triad of dysphagia, iron deficiency anaemia and upper oesophageal webs is termed as Plummer Vinson syndrome (PVS). Since the condition is complicated by gastric squamous cell carcinoma, these patents require regular endoscopic evaluation. However, our patient did not have any complaints of dysphagia as such, but was found to have post cricoid web on endoscopy.

\section{CASE REPORT}

A 56 year old lady presented with fatigue for the past 4 months, which has been progressive and associated with dyspnoea on exertion and palpitations. She did not have any complaints of dysphagia or malena. Her general physical examination revealed a pulse of $100 / \mathrm{minute}$, blood pressure 110/70 $\mathrm{mmHg}$ (no postural drop), respiratory rate $16 /$ minute and normal temperature. She had pallor, glossitis (Figure 1) and koilonychias (Figure 2). An ejection systolic murmur was feebly audible in the aortic area. Other systemic examinations were normal. Her blood investigations showed haemoglobin of $5.4 \mathrm{~g} \%(12-15)$,
MCV 57 fL (79-93) and microcytic hypochromic picture on peripheral blood smear. Her vitamin $\mathrm{B}_{12}$ levels were normal but iron profile showed serum ferritin $3.7 \mathrm{ng} / \mathrm{ml}$ $(10$ - 290), serum iron $276 \mathrm{mcg} \%$ (50-170), total iron binding capacity $562 \mathrm{mcg} \%(250-450)$ and transferrin saturation of $64.10 \%$ (14-50). Other blood parameters like renal and liver functions, thyroid profile, electrolytes and calcium were normal. Anti nuclear antibody profile and anti-cyclic citrullinated peptide were negative. Electrocardiogram showed sinus tachycardia, ultrasound abdomen, echocardiography and chest Xray were normal. Her stool occult blood was positive and upper gastrointestinal endoscopy revealed a partial web at the post cricoid area (upper oesophageal sphincter) and Schatzki's ring at $33 \mathrm{~cm}$ (Figure 3), for which endoscopic dilatation was done. She had grade II haemorrhoids on colonoscopy (Figure 4).

On repeated probing, she mentioned minimal dysphagia at times during swallowing of bolus food. She was given 3 units of packed cell transfusion along with parenteral iron injections, following which her haemoglobin picked up to $9.2 \mathrm{~g} \%$. She was not willing for any surgical intervention for her haemorrhoids and was discharged on iron supplements and Daflon (500 mg twice daily for 1 month), and advised 
high fibre diet and every 6 monthly endoscopic evaluation in view of the risk for developing gastrointestinal carcinoma. After 3 months she was totally asymptomatic with haemoglobin of $11.2 \mathrm{~g} \%$, but was lost for follow up later.

\section{DISCUSSION}

PVS is a rare entity with an unclear pathogenesis. IDA has been implicated as the most probable mechanism. The depletion in the iron dependent oxidative enzymes can lead to myasthenic changes in the muscles of deglutition, atrophic changes in the oesophageal mucosa and formation of epithelial webs. The symptoms of dysphagia show improvements following iron therapy. ${ }^{1}$ However, there have been instances where the patients did not respond to iron therapy and eventually required endoscopic dilatation or incision for the treatment of dysphagia. ${ }^{2-4}$ The occurrence of post cricoid web is a risk factor for the development of squamous cell carcinoma of gastrointestinal tract. ${ }^{5}$ In cases of haemorrhoids, a rapid correction of anaemia has been noticed with hemorrhoidectomy. ${ }^{6}$ PVS has also been observed in conditions like celiac disease, thyroid disorders and rheumatoid arthritis. ${ }^{7-9}$

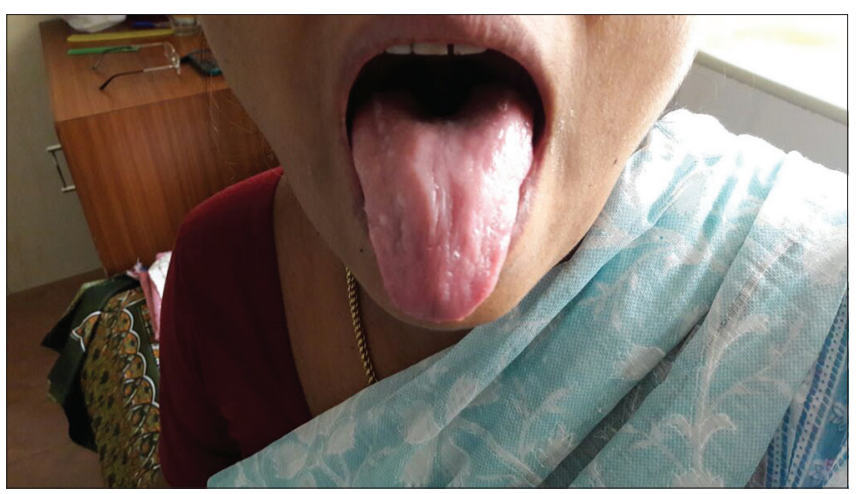

Figure 1: Glossitis

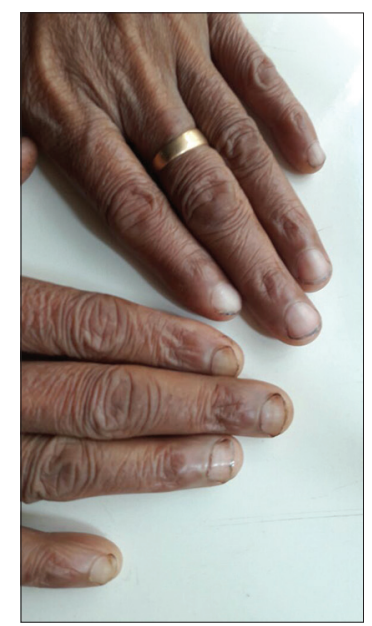

Figure 2: Koilonychia
Our patient did not have any symptom of dysphagia and the presence of post cricoid web was an incidental finding on endoscopy, for which dilatation was done followed by iron therapy. The aetiology for IDA was the presence of grade II haemorrhoids.

\section{CONCLUSION}

PVS is a rare condition and is found mainly in association with IDA. The diagnosis is made when patients fulfil the triad of dysphagia as symptom, IDA on investigation and presence of post cricoid web on endoscopy. The condition can be complicated by gastric carcinoma. Our patient presented with anaemia which was due to iron deficiency from haemorrhoids. She did not have any symptomatic dysphagia but was found to have post cricoid web on endoscopy. This case therefore highlights the possibility of an occult PVS in cases of severe IDA. Since PVS is a risk factor for development of gastric squamous cell carcinoma,

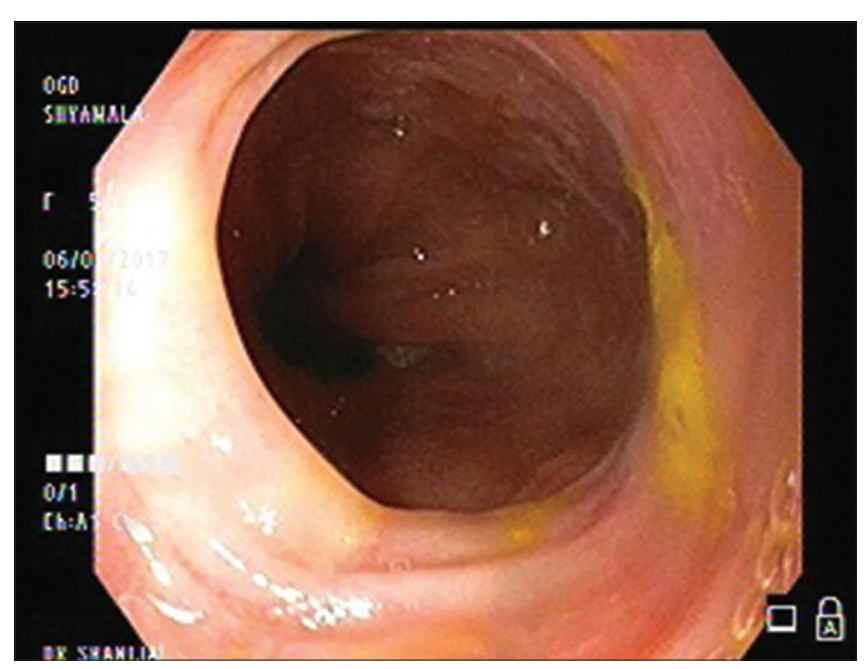

Figure 3: Post cricoid web

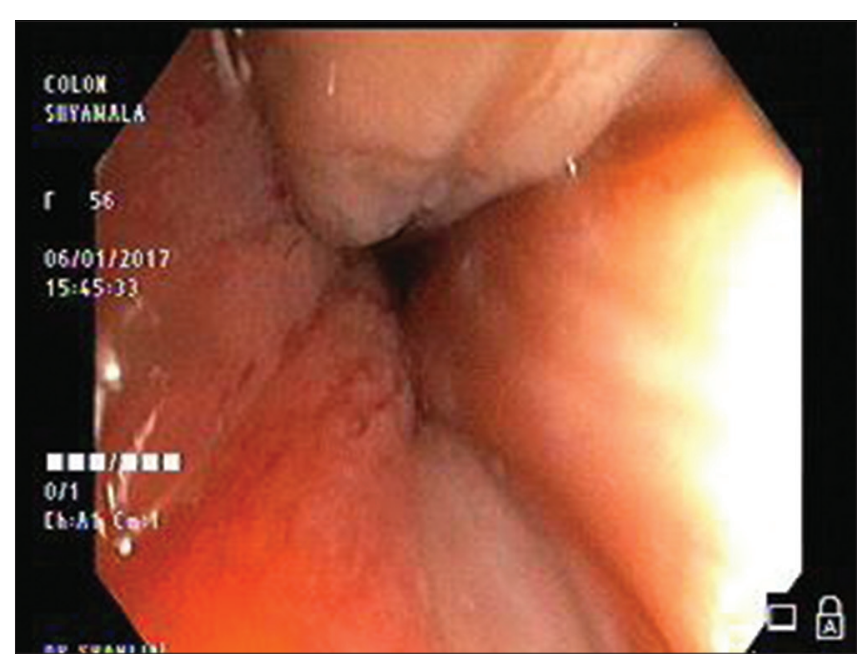

Figure 4: Haemorroids

Asian Journal of Medical Sciences | May-Jun 2017 | Vol 8 | Issue 3 
all patients presenting with severe IDA should be screened for post cricoid web even in the absence of dysphagia.

\section{REFERENCES}

1. Dantas RO and Villanova MG. Esophageal motility impairment in Plummer-Vinson syndrome. Correction by iron treatment. Dig Dis Sci 1993;38: 968-991.

2. Beyler AR, Yurdaydin C, Bahar K, Goren A, Soykan I and Uzunalimoglu O. Dilation therapy of upper esophageal webs in two cases of Plummer-Vinson syndrome. Endoscopy 1996;28:266-267.

3. Enomoto M, Kohmoto M, Arafa UA, Shiba M, Watanabe T, Tominaga $K$, et al. Plummer-Vinson syndrome successfully treated by endoscopic dilatation. J Gastroenterol Hepatol 2007; 22: 2348-2351.
4. Seo MH, Chun HJ, Jeen YT, Park SC, Keum B, Kim YS, et al. Esophageal web resolved by endoscopic incision in a patient with Plummer-Vinson syndrome. Gastrointest Endosc 2011; 74:1142-1143.

5. Chisholm M. The association between webs, iron and postcricoid carcinoma. Postgrad Med J 1974;50:215-219.

6. Kluiber RM and Wolff BG. Evaluation of anemia caused by hemorrhoidal bleeding. Dis Colon Rectum.1994; 37(10):1006-1007.

7. Sood A, Midha V, Sood N and Bansal M. Paterson Kelly syndrome in celiac disease. J Assoc Physicians India 2005; 53: 991-992.

8. Novacek G. Plummer-Vinson syndrome. Orphanet J Rare Dis 2006;1:36.

9. Medrano M. Dysphagia in a patient with rheumatoid arthritis and iron deficiency anemia. Med Gen Med 2002;4:10.

Authors Contribution:

RGM- Concept and design of case report, reviewed the literature, manuscript preparation and critical revision of manuscript, corresponding author and treating

Physician; SP- Critical revision of manuscript and treating Gastroenterologist; RNS- Resident in-charge.

Orcid ID:

Dr. Robin George Manappallil: (1) http://orcid.org/0000-0003-3973-6800

Source of Support: None, Conflict of Interest: None. 